\title{
Relationship Between Executive Education and Governance: Studies of Brazilian Business Groups
}

\author{
Hélder Uzêda Castro ${ }^{1}$ \& Raphael Luiz Guimarães Matos Sobrinho ${ }^{2}$ \\ ${ }^{1} \mathrm{PhD}$ in Regional and Urban Development, CICS.NOVA, New University of Lisbon, Lisbon, Portugal \\ ${ }^{2}$ Master in Administration, PPGA, Salvador University (UNIFACS), Brazil \\ Correspondence: Hélder Uzêda Castro, PhD in Regional and Urban Development, CICS.NOVA, New University \\ of Lisbon, Lisbon, Portugal. E-mail: helderuzeda@gmail.com
}

Received: September 24, 2021

Accepted: October 26, 2021

Online Published: November 13, 2021

doi:10.20849/jed.v5i3.946

URL: https://doi.org/10.20849/jed.v5i3.946

\begin{abstract}
This theoretical and practical discussion intends to connect the formation of human capital of major Brazilian agents with investments in executive education based on demands from the areas of Corporate Governance and Tax. To this end, a literature review of the aforementioned themes was carried out, highlighting historical and contemporary aspects, relating them to the efforts of the companies studied: Petrobras, Braskem and OAS. In addition to the documentary research, semi-structured interviews were carried out with 22 executives from the aforementioned companies in order to reinforce knowledge about the phenomenon of governance, its consequences and consequences in shared services organizations. The text is structured in an introduction, discussion and theory segmented by study area and applied with notes from each business group and conclusions. The scientific contribution lies in strengthening the relationship between what is discussed in the academy and what is done in the market, intensifying the need for corporate education for business results.
\end{abstract}

Keywords: economy, human capital, governance, executive education

\section{Introduction}

Modern literature points out the great economic agents as important centers for the formation of human capital. The demands of organization, regulation and market contribute to significant investments in the executive education of thousands of people in geographic spaces, in Brazil or in the world.

Regional inequality prevails and some authors argue that the process of economic development does not occur equally and simultaneously. On the contrary, it is a very irregular process and, once started in certain places, it has the characteristic of strengthening more diligent areas that present greater growth potential, through people and organizations.

The economy is in constant motion, the familiar cycles. To accompany a new world development process, in which services (technologies, processes) and intellectual capital (people), discussed by Stewart (1998), replaced physical capital (facilities), previously considered the key variable of economic growth, organizations started to invest in the concentration, precisely, of technologies, processes and people. The latter with the challenge of forming and retaining them. This research highlights the role of shared service centers in corporate education, based on intensified programs to meet new operational requirements, many of them corporate governance and tax practices.

It is understood that human capital represents an important instrument for the development of the organization, and, when allocated and concentrated on shared service, it promotes impacts in the region in which the operation is installed, contributing to development not only of an economic nature, but also with the dynamics of the social structure.

The purpose of this work is to analyze the service sharing model of three Brazilian business groups: Petrobras (energy), Braskem (petrochemicals) and OAS (civil construction); and verify investments in human capital formation in the periods before and after the COVID-19 pandemic. Corporate documents, public accounting or accountability information were accessed, and key executives who work in the personnel areas of the companies studied were interviewed. 


\section{Methodology}

This work was prepared from a literature review in the areas of Human Capital, Governance and Corporate Education, connecting them with the efforts of three important Brazilian business groups, aiming to understand how the demands of corporate and tax governance promote capital formation human being in shared service centers. To this end, analyzes were carried out on documents from the companies Petrobras, Braskem and OAS, as well as semi-structured interviews with 22 executives who work in the People areas of the companies studied. Under the most current and certainly empirical aspect, the objective is to broaden the discussion of education and the inclusion of professional training programs as an important strategy for human and organizational development.

\section{Theory and Discussion}

\subsection{Human Capital Theory}

The Human Capital Theory, formalized by Theodore Schultz (1973), manages to propose the understanding of the human being as one of the main factors of wealth production, through knowledge as a form of capital. In this sense, education came to be valued as an element of investment and importance in the development process of the country or region, as well as of the organization itself.

Endogenous factors of production, such as human capital, are determined within the region and contribute to its accelerated and balanced development, mainly within an economy increasingly based on flexibility, knowledge, information and technology. Thus, information has become the most valued asset in the Post-Industrial Economy and the regional development of the knowledge-based economy stands out in the construction of an established advantage.

The sharing of services is a movement that has been observed in the world market since the 1980s, when the centralization of back-end (ie, administrative) services associated with the Financial, Human Resources and Technology Services areas of the Information (DELOITTE, 2017). As a result, the company becomes more competitive and competitiveness is one of the great topics under debate when discussing success in the business environment. Also regarding the study, there is no right way to define the presence of its Shared Services, service coverage and governance, as they are very unique in relation to the conditions, future goals and current pressures of each organization, which can be a problem for planning and implementation.

The investigation of studies on human capital in Smith ([1776] 1983) and Marshall ([1890] 1996), one can observe the issue converging to the understanding of education and human capacity as investment, income, poverty eradication in mass and development in a multidimensional perception. Smith, in his work Wealth of Nations ([1776] 1983), analyzes the real expenditure on education and the fixed capital invested in the individual, once the application of capital in this area actually takes place.

This theoretical framework not only provides intellectual growth but also increases the possibilities of absorption in the labor market in accordance with regional demands (SCHULTZ, 1973, p. 18). However, this same economist warns that

While it is obvious that people acquire useful skills and knowledge, it is not obvious that these skills and knowledge are a form of capital, that this capital is, in substantial part, a deliberate investment product, which has grown, in Western societies, into a rate much faster than conventional (non-human) capital and this growth may be the most distinctive feature of the economic system.

Based on what Schultz (1973) advocates, it can still be seen that there is a direct relationship between human capital and income distribution. "Changes in investments in human capital are a basic factor in reducing inequalities in the personal distribution of income." (SCHULTZ, 1967, p. 82).

Human capital is the result of investment in man. As a result, there will be developments in a broad sense, changes in the dynamics of understanding knowledge and in culture. The Human Capital Theory represents, among other aspects, the degree of capacity of the community for qualified work. This dynamic unfolds in the use of new technologies and a certain degree of innovation both in the public and private spheres (FONSECA, 1992).

Petrobras has a financial operations center located in the city of Rio de Janeiro, the company's headquarters. It houses thousands of employees dedicated to the management of the economic group. All regularly undergo training in their areas of expertise. In tax enforcement, there are more than 600 people trained in the areas of administration, economics, accounting, law and technology. The corruption scandals and the COVID-19 pandemic 
have not reduced investments in education, including increasing resources in programs for the development of digital skills.

Braskem uses a digital shared service, through a platform that integrates transactional and corporate operations, located in the cities of Salvador and São Paulo, respectively. This is a model that facilitated the continuity of work and performance during the pandemic. The so-called framework has online education tools widely used during the pandemic. The company has a few hundred professionals. It is recognized in the market for the quality of training programs and the human capital allocated.

OAS brought together two shared operations in the city of Salvador and due to the corruption scandals and institutional crisis it significantly reduced the number of employees, as well as the investment in training programs. Of the 120 thousand existing employees, 108 thousand were dismissed, then moving to a staff in 2019 of 12 thousand employees. Part of the company's strategy is to rebuild the workforce with qualified personnel.

Complex operations require skilled workers. The personal and business efforts in training are enormous. In order to comply with Brazilian regulation, mainly in tax aspects, for the purposes of this governance research, economic agents invest in structure, processes and technology to reduce corporate risks.

\subsection{Corporate and Tax Governance}

The study of Corporate Governance had its origins in the increase in the level of complexity of companies, which, in turn, was accompanied by the dispersion of the controlling capital of these organizations. Nineteenth-century photography portrayed organizations backed by individual or restricted-group property structures, and whose management acts were performed directly by their owners or their agents (SERAFIM, QUELLAS; ALLEDI; 2010, p.4).

Berle and Means (1932) - whose work The Modern Corporation and Private Property is referenced by authors such as Serafim, Quellas and Alledi (2010) and Saito and Silveira (2008), as being the starting point of corporate governance studies - propose to discuss the conflicts of interest of dispersed ownership structures and their effects on the performance and value of companies, having as object of study the shareholding composition of large North American companies.

It is worth recovering embryonic initiatives of codification of good Corporate Governance practices that took place in the United States (late 70s), the creation of the code of good governance in Hong Kong (1989), the creation of the Statement of Best Practice on the Role in Ireland and Responsibility of Directors of Publicly Listed Companies (1991) and Financial Aspects of Corporate Governance in the UK, known as Cadbury report (1992)

In the USA, the Securities Exchange Commission, the New York Stock Exchange, and the Roundtable, among others, have continued to issue codes since the late 1970s. However, it was not until a decade later that another country created a code of good governance. In 1989, the Hong Kong Stock Exchange issued its first 'Code of Best Practice, Listing Rules', and in 1991 the Irish Association of Investment Managers drafted the 'Statement of Best Practice on the Role and Responsibility of Directors of Publicly Listed Companies'. Nevertheless, the development of codes grew rapidly in the early 1990s, following the 1992 Cadbury Committee Report: Financial Aspects of Corporate Governance in the UK. (AGUILERA E CUERVO-CAZURRA, 2009, p. 418-419).

Also according to the authors, in the 30 years since the first code was issued in the United States, good governance codes have been created in 64 developed, transitional and developing countries. However, it is known that this effort was intensified, in part inspired by the Cadbury Code, created in the United Kingdom in 1992. The dissemination of good governance codes around the world was aided by the impulse of international entities.

In this context, business groups started an important movement that gained notoriety in the 1990s towards better governance practices. In Brazil, Petrobras was one of the first companies to discuss the issue with its stakeholders, previously an organization of engineers that did not show concern with transparency in management and accountability. Only with production and distribution.

Braskem, formed by the integration of six other Odebrecht Organization companies and the Mariani Group, adopted governance levels when planning and implementing its shared services model. This research was not able to identify when OAS started the negotiation, but it is known that the company is currently seeking to re-establish itself and, therefore, it needs an excellent governance program, meeting the pillars, but also focusing on finance and taxes. 
The complexity of the management activity has motivated the adoption of practices derived from Corporate Governance that aim to optimize - in an ethical, controlled and transparent way - the results. Specifically in terms of the tax enforcement activity, these managers still need to spread practices in organizations that are also permeated by transparency, fairness, accountability and compliance.

Due to the importance given to the tax issue in companies and its effects on society, especially in Brazil, it is assumed that Corporate Governance in the scope of tax enforcement reaches a second level.

Tax Governance represents a set of procedures and tools designed and implemented from the perspective of the principles of Corporate Governance, applied by managers working in the area of tax enforcement. Castro (2013) argues that this should be developed from corporate governance, process management and tax management, with the use of information technology - management, controllership, auditing and communication systems with government entities -, which it requires highly specialized human capital and therefore investment in executive education.

\subsection{Executive Education}

Organizations are fundamentally made up of people, who contribute to their performance and success through their actions, and the training of these employees favors the company globally. Thus, according to PricewaterhouseCoopers (PWC) consultancy (2016, p. 1), "Corporate education systems [EC] therefore have a fundamental role in improving business competitiveness and, indirectly, in the social conditions of the parents".

PWC (2016, p. 4) continues the reasoning, stating that

The development of a country necessarily depends on results in the area of education. Despite the advance in investments made in recent years, the level of education in Brazil is still far from what is expected for the country to achieve economic competitiveness and overcome social and regional inequalities. As a result of this educational scenario, companies in Brazil have great difficulty in finding professionals with the necessary qualifications to implement their business strategy.

Thus, currently, the view that strategy depends on learning and that it depends on the development of individuals' capacities has become very popular. This approach tends to consider strategic management as a process of "collective learning", which aims to develop and explore distinct competences, difficult to be imitated, providing a competitive advantage for organizations (PRAHALAD; HAMEL, 1990, p. 82).

According to Hall (2002), human capital is the sum of knowledge of everyone within a company, which provides it with a differential and a unique positioning in the market, being, therefore, the result of interaction and collaboration between people, sharing and continuous learning in an organization.

Still following Hall (2002), a company that only invests in machinery, equipment and technologies no longer makes a difference, as equipment and technologies are goods available on the market and any corporation can acquire them; while intellectual capital, an intangible asset with a peculiarly generated value, belongs not only to the economic agent, but to each employee.

To understand how education should be processed at the corporate level, PWC (2016, p. 5) developed a strategic management model for this type of education (Figure 4), which assumes that the DE system should enable "[... .] the organization's strategic objectives, through the construction of the necessary competences, the alignment of the behavior of professionals and the development of the corporate culture", that is, to improve human capital so that it increases its value and, consequently, its value the organization, as well as the region and the country.

With a focus on fulfilling this purpose, the referred system ends up articulating three main aspects: 1) the strategic positioning of professional development, which delimits the mission and objectives of the CE system, and expresses its value proposition, that is, it explains why the company should invest in organizational learning; 2) the CE's business and corporate governance model "[...] defines the organization and management architecture so that the education system fulfills its objectives" (PWC, 2016, p. 6); and 3) its operating model "[...] defines the processes and infrastructure necessary for the system to generate the expected results." (PWC, 2016, p. 6).

This so-called corporate education can take place either as Training and Development (T\&D) or as the well-known Corporate Universities. For the purposes of this work, attention was focused only on the second.

Tarapanoff (2004, p. 17), historiographing on the phenomenon of the Corporate University (UC), states that this

[...] emerged as an unfolding or deepening of the training activities of the Human

Resources Departments in the companies. In the beginning, its focus, in the United 
States, was the training of its employees, seeking to improve their professional skills and proficiency in their activity within the corporation (expertise development). From its inception, it reflected a clear industry commitment to educating its employees - the kind of education that can keep the company competitive. (DAVIS; BOTKIN, 1994).

There are some definitions for what PAs are, but for this study, Mark Allen's (2002, p. 9-10) is more adequately applied, namely:

An educational entity that becomes a strategic instrument. Designed to assist your organization (supporter) to achieve its mission, conducting activities that create a culture of individual and organizational learning, and lead to knowledge and wisdom.

This concept clearly makes it clear that UC is strategic as an instrument, among the many that the organization has at its disposal, which aims to help its supporting organization to fulfill its mission, improve its business and gain competitiveness against its competitors, as well how to return improved human capital to the region. Today, it is constantly emphasized that what makes a university truly corporate is its connection to strategy.

Fresina (1997) points out three distinct strategic roles that PAs can play: 1) reinforce and perpetuate behavior: here, the main concern is to provide training courses and experiences that reflect and reinforce the organization's culture and values ; 2) manage the change process: in this, the main concern is to introduce and promote organizational change initiatives, in this way, programs and activities are designed to facilitate the formulation and implementation of strategic change; and, finally, 3) directing and shaping the corporation: which is perhaps the most ambitious and, by inference, the least visible concern, in it, leaders use UC as the driving force to shape future business directions, in this way, change programs and initiatives aim to explore new contexts and future alternatives for economic agents.

Tarapanoff (2004) argues that the best corporate universities are those that exist to help corporations achieve their goals. In this regard, it is worth noting that: Petrobras' operations center concentrates the activities of the Financial, Accounting and Tax areas of national and international units. It is a global effort to fulfill obligations and deliver results to shareholders and other stakeholders; Braskem's shared service in Salvador covers the main transactional activities for the management of industries located a few kilometers away, in the city of Camaçari, in the metropolitan region, and from São Paulo, the global strategic processes of the economic conglomerate; and the OAS service center brings together all activities related to the company's management and is increasingly concentrated due to the reduction in the workforce.

At this point, it is important to emphasize that all executive education initiatives of the companies studied are aligned with business demands and strategies. Employees are encouraged to invest time and study in learning about continuous improvement tools, in this survey, focusing on the demands of corporate and tax governance.

At Petrobras they become experts in governance, compliance and internal controls, as well as in risk management. They also learn international accounting standards and the application of the Anti-Corruption Law (Brazil) and the Sarbanes-Oxley Law (USA) through the well-known SOX controls.

\section{Conclusions}

The first impressions about the economic value arising from human capital, we start to deal with the conceptuais bases of the theory about this capital, which are mainly focused on the epistemological studies of the American economist Theodore Willian Schultz. It is understood that this prominent theorist was responsible for noticing a gap in economic theories in relation to economic efforts, knowledge, its cost in different spheres and the return coming from individuals prepared for formal work.

The need to equalize internal and external forces in organizations, therefore, was a driving factor for the need to carry out studies focused on the corporate world and its numerous relationships with society, discussions that are anchored in ethical aspects and business sustainability, through the formation of human capital.

Each economic agent exists for a reason and this is usually explained in their mission. Most companies develop strategies or plans to accomplish this mission. Having a corporate university should not be seen as an organizational objective, but as an instrument to help the company achieve its objectives. In Brazil, this equipment works to meet the operational needs of shared service centers, often operating within the same physical or digital structure.

The research showed that, despite the corruption and pandemic scandals, Petrobras, Brazil's largest taxpayer, has increased its investments in human capital formation, with an emphasis on the use of emerging technologies, 
aiming to meet the organizational, regulatory and marketing demands imposed by principles and practices of corporate governance and taxes. And you should follow this trend on account of remote work.

Braskem maintained an executive education program on its digitais platform that houses shared services strategically located in two Brazilian cities. In this research, OAS was the only one that showed a significant reduction in the workforce and, consequently, in investments in human capital. The interviews indicate that the company is seeking recovery with the support of workers already qualified in the rehiring movement, which has yet to be planned.

All executives interviewed highlighted the importance of the human component in the development of these organizations, even considering that governance models need to be more discussed and assertive. They are present at all corporate meetings or strategic moves and retention is the second concern. The first one is still training.

\section{References}

Aguilera, R. V., \& Cuervo-Cazurra, (2009). A. Codes of good governance worldwide: What is the trigger?. Organization Studies, 25(3), 415-443.

Allen, M. (2002). Introduction. In Corporate University Handbook: designing, managing, and growing a successful program. New York, USA: Amacon.

Castro, H. U. (2013). Fatores que contribuem para o desenvolvimento da governança tributária: um estudo de caso sobre a estruturação da administração tributária da Petrobras. $224 \mathrm{f}$. Dissertação (Mestrado em Administração) - Programa de Pós-graduação em Administração, Universidade Salvador, Salvador, Bahia.

Deloitte. (2017). Pesquisa Global de Serviços Compartilhados de 2017. São Paulo: Deloitte.

Fonseca, E. G. da. (1992, Abr-Jun.). O capital humano na Filosofia Social de Marshall. Revista de Economia Política, 12(46), 64-87.

Fresina, A. J. (1997, Jan.-Feb.). Three Prototypes of Corporate Universities. Corporate University Review, 18-20.

Hall, D. T. (2002). Careers in and out of organizations. London: Sage.

Marshall, A. (1996). Princípios de economia: tratado introdutório (Vol. 1. 2nd ed.). Tradução revista de Rômulo Almeida e Ottolmy Strauch São Paulo: Nova Cultural, [1890].

Prahalad, C. K., \& Hamel, G. (1990, May-June). The core competence of the corporation. Harvard Business Review, 68(31), 79-91.

PWC. (2016). Modelos e práticas de educação corporativa nas organizações brasileiras. São Paulo: PricewaterhouseCoopers Brasil.

Schultz, T. W. (1967). O valor econômico da educação. Tradução de P. S. Werneck. Rio de Janeiro: Zahar.

Schultz, T. W. (1973). O capital humano: investimentos em educação e pesquisa. Tradução de Marco Aurélio de Moura Matos. Rio de Janeiro: Zahar.

Serafim, E., Quelhas, O. L. G., \& Alledi, C. (2010). Histórico da governança corportativa: contribuições para a sustentabilidade das organizações. In CONGRESSO NACIONAL Niterói DE EXCELÊNCIA EM GESTÃO, 6 , 2010, Niterói. Anais... Niterói (RJ): UFF.

Smith, A. (1983). A riqueza das nações. Tradução de Luiz João Baraúna. São Paulo: Abril Cultural, [1776].

Stewart, T. A. (1998). Capital Intelectual: a nova vantagem competitiva das empresas (2nd ed.). Rio de Janeiro: Campus.

Tarapanoff, K. (2004). Panorama da Educação Corporativa no Contexto Internacional. In Secretaria De Tecnologia Industrial (Org.), Educação Corporativa: contribuição para a competitividade (pp. 12-84). Brasília: Petróleo Brasileiro, CNI.

\section{Copyrights}

Copyright for this article is retained by the author(s), with first publication rights granted to the journal.

This is an open-access article distributed under the terms and conditions of the Creative Commons Attribution license (http://creativecommons.org/licenses/by/4.0/). 